\title{
PEGMATITES IN SOUTHEASTERN BRAZIL
}

\section{ESSAÏD BILAL ${ }^{1}$, JOSÉ MARQUES CORREIA NEVES ${ }^{3}$, KAZUO FUZIKAWA ${ }^{3}$, ADOLF HEINRICH HORN ${ }^{2}$, VITÓRIA RÉGIA PERES DA ROCHA OLIVEIROS MARCIANO ${ }^{2}$, MARIA LOURDES SOUZA FERNANDES ${ }^{2}$, JAQUES MOUTTE ${ }^{1}$, FERNANDO MACHADO DE MELLO ${ }^{1}$ AND MOHAMED NASRAOUI}

\begin{abstract}
Two pegmatite groups are represented in southeastern Brazil. The first group, resulting from fractional crystallization, is linked to syn-tectonic granites $\left(580 \mathrm{Ma}\right.$ - deformation event $\left.\mathrm{D}_{1}\right)$ and the second one is associated with another partial melting event of the crust which simultaneously produced porphyritic leucogranites [(520-500 Ma)- later deformation event $\mathrm{D}_{2}$ ] and pegmatites themselves. The Fe/Mn ratios of tourmalines, micas and columbite-tantalites decrease continuously from simple pegmatites to gem quality elbaite-rich ones. The Fe/Mn ratio has been used as a qualitative fractionation index which seems to reflect the regional zoning of the first pegmatites group around a hidden granite body. The Fe/Mn ratio values correlate negatively with $\mathrm{Na}$ and Li contents in tourmalines and mica. The REE, Nb, Co and $\mathrm{Zn}$ contents in tourmalines, micas, and columbite-tantalites are controlled by their mineral assemblages.
\end{abstract}

Keywords: Schorl, elbaites, gems, columbite-tantalite, Li-pegmatites, Minas Gerais-Brazil.

INTRODUCTION Pegmatites from southeastern Brazil can be classified in two groups, namely: (i) Gem-quality tourmaline rich and zoned Li-bearing pegmatites; and (ii) Beryl-bearing, sometimes of gem-quality, ceramic simple pegmatites. The first group results from fractional crystallization of magma and is linked to the syn-tectonic granites (Bilal et al. 1998a). The syn-tectonic magmatic series are related to crustal melting produced by decompression and thermal relaxation $\left(550-700^{\circ} \mathrm{C}, 4-5 \mathrm{kbar}\right)$. They consist of leucogranites and zoned Li-bearing pegmatites whose emplacement at $582 \mathrm{Ma}$, is controlled by a previous main compressive deformation phase D1. This first group of pegmatites is located in a pegmatite district encompassing Governador Valadares, Teófilo Otoni, Galiléia, Araçuaí, and Cruzeiro (São José da Safira) (Fig. 1: fields A and B).

The pegmatites have been grouped according to the metamorphic grade of their country rocks as well as to their degree of evolution as pointed out by their accessory mineralogy and mineral geochemistry (Correia-Neves et al. 1986, 1987, Correia-Neves 1997).

The second pegmatite group is late to the previous group. It is associated to the second deformation D2 of the Brasiliano event (from 520 to $500 \mathrm{Ma}$ ). During the D2 event a partial melting of the crust occurred generating simultaneously the porphyritic leucogranites and the second group of pegmatites (Be-bearing and simple ceramic pegmatites) (Bilal et al. 1998a). Petrological and chemical characters of porphyritic granitoids indicate a crustal origin different from that of syn-tectonic suites. The source material of magma is probably the high-grade metamorphic rocks, i.e. orthogneisses and/or paragneisses. The second group is located in a pegmatite district encircling Caparaó, Espera Feliz, Marilac, and Santa Maria de Itabira (Fig. 1: fields C and D).

The main purpose of this paper is to interpret the chemical and mineralogical compositions and other differences between these pegmatites.

PEGMATITES: GEOLOGICAL SETTING, MORPHOLOGY, AND MINERALOGY The first pegmatite group

Hundreds of pegmatites have been emplaced in the Rio Doce Group metasedimentary sequence which displays medium grade amphibolite type metamorphism. They are concordant and discordant to the earlier Brasiliano structures. They show outcropping lengths ranging from 150 up $1,300 \mathrm{~m}$ and widths of 10 up to $60 \mathrm{~m}$. They are subvertically emplaced bodies striking $\mathrm{N} 10-20 \mathrm{~W}$. The internal structures are essentially very similar in all of them (Correia-Neves et al. 1986; 1987, Correia-Neves 1997, Bilal et al. 1997). They show consistent mineral assemblages arising from an internal zoning around the quartz core. The centimetric minerals were collected either from the primary zones or even from later metasomatic pockets. The schorlitic tourmalines are always associated with quartz, muscovite, K-feldspar, garnet, columbite-tantalite $(\mathrm{Nb}>\mathrm{Ta})$ and prismatic beryl from primary crystallization. However, the elbaitic ones are found only together with cleavelandite, quartz, ambligonite, spodumene, phosphates, Li-rich violet micas, tabular morganite, tantalite-columbite $(\mathrm{Ta}>\mathrm{Nb})$ of the later crystallization stage.

Fluids trapped in primary fluid inclusions in green tourmaline taken in the Cruzeiro Pegmatite, from the first pegmatite group, are

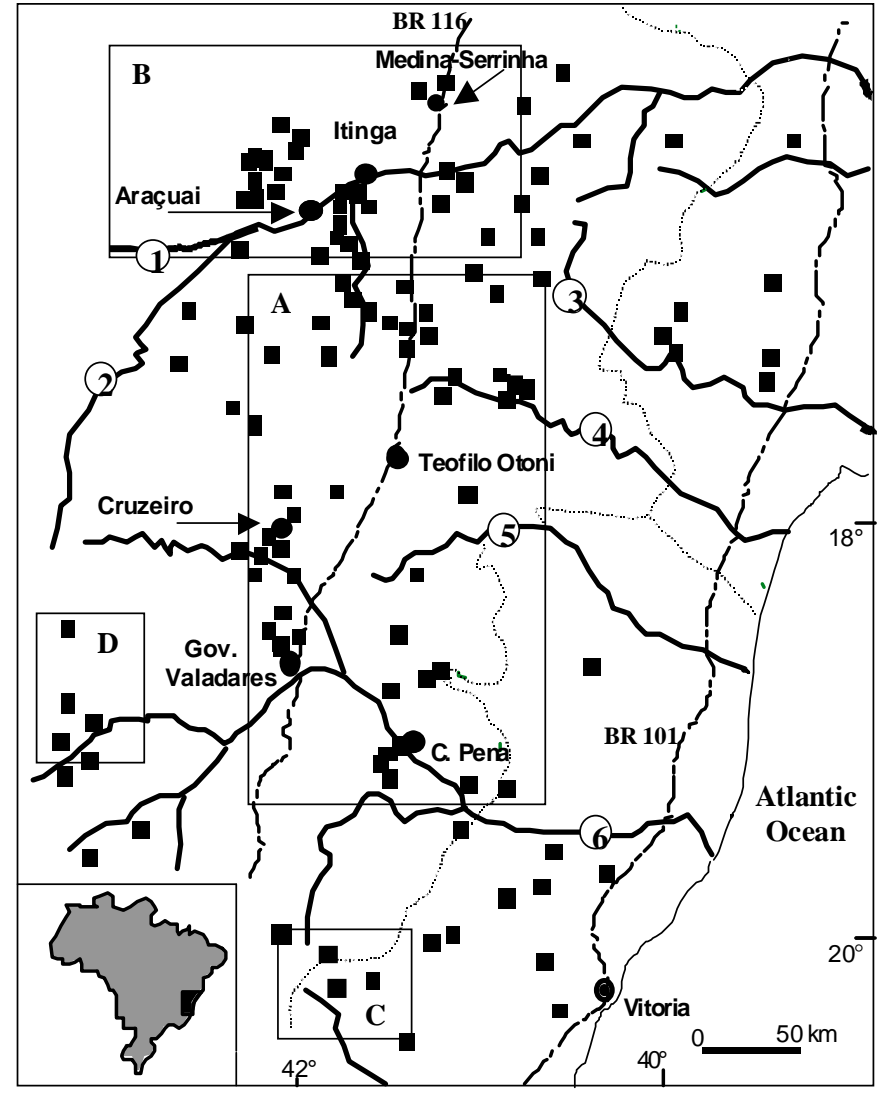

Figure 1-Distribution fields of pegmatites in southeastern Brazil. Pegmatites from the first group are in A (Governador Valadares, Teófilo Otoni, São José da Safira and Galiléia); and B (Araçuai and Itinga). Pegmatites from the second group are in C (Caparaó and Espera Feliz) and D (Santa Maria de Itabira). Dots: Federal State Boundaries. Roman Numerals: Federal States (IBahia; II- Espírito Santo; III- Minas Gerais). Open circles with arabic numerals: Rivers [(1)-Jequitinhonha; (2)-Araçuai; (3)-Itanhém; (4)-Mucuri; (5)-São Mateus; (6)-Rio Doce]. BR 116 and 101: Federal Highways. Black squares: pegmatites. Black circles: towns.

essentially of $\mathrm{H}_{2} \mathrm{O}, \mathrm{CH}_{4}$ and $\mathrm{N}_{2}$ (Fuzikawa et al. 1996). They were confirmed by Raman spectroscopy. The total homogenization temperatures of these inclusions range from 300 up to $400^{\circ} \mathrm{C}$. Minimum pressure estimates are from 0.6 to $1.1 \mathrm{kbar}$. The mineral assemblage in these pegmatites indicates that the tourmalines were crystallized under $360^{\circ} \mathrm{C}$ to $570^{\circ} \mathrm{C}$ temperature and a pressure of 1.1 kbar to 3 kbar (Bilal et al. 1997). 


\begin{tabular}{|l|l|}
\hline Pegmatite Type & Essential and Accessory Mineralogy \\
\hline 1) beryl pegmatite & $\begin{array}{l}\text { Quartz, K-feldspar, biotite, muscovite, Ca-poor plagioclase, schorl, garnet, } \\
\text { prismatic-beryl, primary and secondary phosphates, and columbite-tantalite } \\
(\mathrm{Nb}>\mathrm{Ta}) .\end{array}$ \\
\hline 2) beryl spodumene pegmatite & $\begin{array}{l}\text { Quartz, K-feldspar, muscovite, Li-bearing micas, cleavelandite, gem quality- } \\
\text { elbaitic tourmalines, garnet, beryl, spodumene, amblygonite, columbite-tantalite } \\
(\mathrm{Nb} \approx \mathrm{Ta}), \text { cassiterite and Mn-apatite. }\end{array}$ \\
\hline 3) spodumene pegmatite & $\begin{array}{l}\text { Quartz, K-feldspar, muscovite, Li-bearing micas, cleavelandite, gem quality } \\
\text { elbaites, garnet, prismatic- blue and tabular-pink beryl, spodumene, amblygonite, } \\
\text { tantalite-columbite }(\mathrm{Nb}<\mathrm{Ta}), \text { gahnite, cassiterite and Mn-apatite. }\end{array}$ \\
\hline
\end{tabular}

Table 2 - Morphology and Mineralogy of second pegmatites group

\begin{tabular}{|c|c|}
\hline Zone & Essential and Accessory Mineralogy \\
\hline Marginal & $\begin{array}{l}\text { Quartz, biotite, K-feldspar, muscovite, Ca-poor plagioclase which becomes } \\
\text { cleavelandite when fluorite, of the same paragenesis, becomes a major } \\
\text { mineral as it happens in Generosa Mine, garnet (almandine-spessartine). }\end{array}$ \\
\hline Mural & $\begin{array}{l}\text { Graphic quartz, K-feldspar, muscovite, beryl, monazite-(Ce), apatite, } \\
\text { columbite-tantalite }(\mathrm{Nb} » \mathrm{Ta}) \text {. }\end{array}$ \\
\hline Intermediate & K-feldspar, muscovite, quartz. \\
\hline Core & Quartz. \\
\hline Other Accessory Minerals & $\begin{array}{l}\text { Amazonite, prismatic blue beryl, cleavelandite, apatite, fluorite, columbite- } \\
\text { tantalite } \quad\left[(\mathrm{Fe}, \mathrm{Mn})(\mathrm{Nb}, \mathrm{Ta})_{2} \mathrm{O}_{6}\right], \quad \text { euxenite- } \mathrm{Y} \quad \text { topaz, } \\
\left.\mathrm{U}, \mathrm{Th})(\mathrm{Nb}, \mathrm{Ca}, \mathrm{Ce}, \mathrm{Ti})_{2} \mathrm{O}_{6}\right], \quad \text { samarskite- } \\
(\mathrm{Y})\left[\left(\mathrm{Fe}^{3+}, \mathrm{Y}, \mathrm{Fe}^{2+}, \mathrm{U}, \mathrm{REE}\right)(\mathrm{Nb}, \mathrm{Ta}, \mathrm{Ti}) \mathrm{O}_{4}\right], \\
{\left[\left(\mathrm{Ca}, \mathrm{Na}_{2} \mathrm{Ta}_{2} \mathrm{O}_{6}(\mathrm{O}, \mathrm{OH}, \mathrm{F})\right] \text { as inclusions, wulfenite }\left(\mathrm{PbMoO}{ }_{4}\right) \text {, bismuthinite }\right.} \\
\left(\mathrm{Bi}_{2} \mathrm{~S}_{3}\right) \text {, huttonite }\left(\mathrm{ThSiO}_{4}\right) \text { et cheralite }\left[(\mathrm{Ca}, \mathrm{Ce}, \mathrm{Th})(\mathrm{P}, \mathrm{Si}) \mathrm{O}_{4}\right] .\end{array}$ \\
\hline
\end{tabular}

The second pegmatite group These pegmatites are well represented in an area stretching from Itabira spreading out toward Guanhães in Santa Maria de Itabira pegmatite district, in Caparaó-Espera Feliz district, and Marilac area (Correia-Neves 1999). They have been emplaced either in ortho- and para-gneisses $(2.6 \mathrm{Ga})$ or in Borrachudos Granite (1.7 Ga.) in Santa Maria de Itabira pegmatite district. These bodies display a zoned distribution around anatectic zone showing a greater evolution when emplaced in higher levels from this anatectic root. Monazites from pegmatites and migmatites have the same age from 450 to $520 \mathrm{Ma}$ and $512 \mathrm{Ma}$, respectively (Bilal et al. $1998 \mathrm{~b}$ ). Titanites from migmatites have an age of $509 \mathrm{Ma}$. The $\mathrm{Rb} / \mathrm{Sr}$ and K/Ar ages in micas and K-feldspars are between 409 and $509 \mathrm{Ma}$.

The pegmatites show thickness ranging normally from 0.5 up to 10 $\mathrm{m}$, or sometimes even greater. The morphology of bodies is predominantly tabular or lens shaped. They show an internal zoning especially evident in larger bodies.

Fluid inclusion microthermometry in minerals of primary stages indicate that crystallization occurred in the pressure range of 2 to 2.75 kbar and at temperature of $450^{\circ} \mathrm{C}$ to $650^{\circ} \mathrm{C}$. The lower limits, of $450^{\circ} \mathrm{C}$ and $2 \mathrm{kbars}$, correspond to late hydrothermal stage in the postmagmatic evolution of host pegmatites, marked by an extensive albitization (Bilal et al. 1998b). All analyzed monazites-(Ce) show the effect of two coupled substitutions: (1) $\mathrm{REE}^{3+}+\mathrm{P}^{5+}=(\mathrm{Th}, \mathrm{U})^{4+}+\mathrm{Si}^{4+}$; and (2) $2 \mathrm{REE}^{3+}=(\mathrm{Th}, \mathrm{U})^{4+}+\mathrm{Ca}^{2+}$. Th-rich primary monazite-(Ce) seems to have had higher contents of cheralite and huttonite in the solid solution. During the albitization, the rims of monazite-(Ce) are altered and fractured. The accessory mineral assemblages change; huttonite and cheralite crystallize together with Th-poor and La-rich monazite-(Ce) according to the (3) and (4) reactions: (3) 1 Monazite- $(\mathrm{Ce}, \mathrm{Th})=0.81$ Monazite- $(\mathrm{Ce}, \mathrm{La})+0.19$ Huttonite (4) 1 Monazite- $(\mathrm{Ce}, \mathrm{Th})=0.93$ Monazite- $(\mathrm{Ce}, \mathrm{La})+0.06$ Huttonite +0.01 Xenotime.

During this late stage, $\mathrm{Nd} / \mathrm{Sm}$ and $\mathrm{U} / \mathrm{Pb}$ ratios in monazite-(Ce) have also changed.

PEGMATITE MINERAL CHEMISTRY SIGNATURE Micas and feldspars The $\mathrm{Rb}$ and $\mathrm{Cs}$ contents of the micas and $\mathrm{K}$ feldspars in the second pegmatites group are lower than those observed in the first pegmatite ones. They represent the lower degree of evolution of these pegmatites. These pegmatites are the less differentiated ones, showing a low fractionation as indicated by high $\mathrm{Na}_{2} \mathrm{O}$ content and high K/Cs ratio in K-feldspars. The Cs content of mica and K-feldspars in the first pegmatite group increase continuously from simple pegmatites to the elbaitic gem-rich pegmatites. It correlates positively with $\mathrm{Rb}$ and negatively with the ratio $\mathrm{K} / \mathrm{Rb}$.

$\mathrm{The} \mathrm{Nb}$ content of mica increases up to $160 \mathrm{ppm}$ decreasing afterwards. This distribution pattern is correlated to the onset of columbite-tantalite crystallization. 


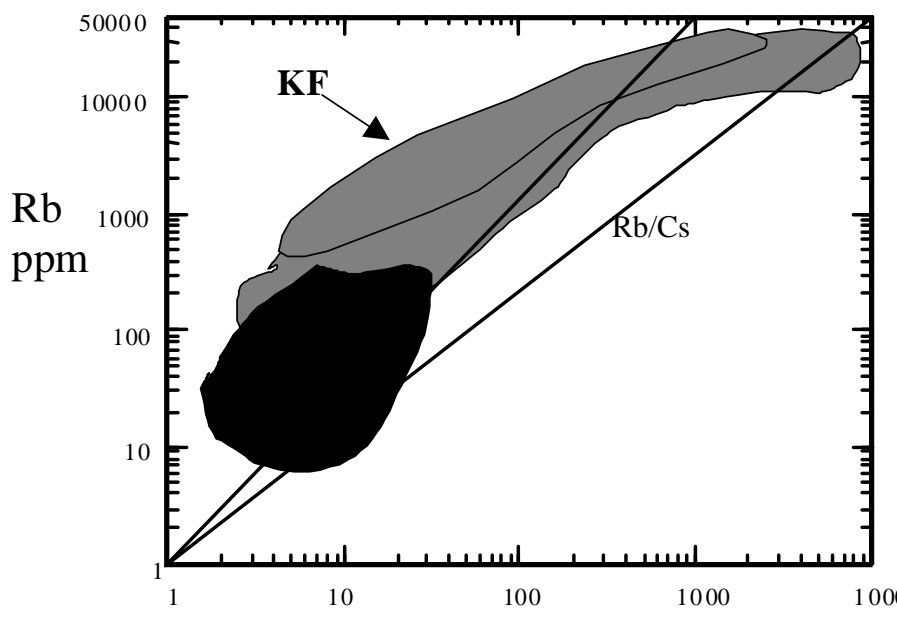

Cs ppm

Figure 2-The Rb/Cs weight ratios in micas and $K$-feldspars attain very low values. Dashed area: $K$-feldspars and micas from first pegmatite group; black area: micas from second pegmatite group.

Columbite-tantalites They evolve from ferrocolumbite to mangano-tantalites. $\mathrm{Fe} / \mathrm{Mn}$ and $\mathrm{Nb} / \mathrm{Ta}$ ratios are considerably lowered in the most evolved pegmatites. Using these minerals, two distinct evolution trends can be observed. The first one concentrates around an almost constant $\mathrm{Fe} / \mathrm{Mn}$ ratio and is, therefore, concerned to internal evolution within every pegmatite. The second evolution trend is characterized by a regional increase in concentrations of Ta and by a decrease of $\mathrm{Fe} / \mathrm{Mn}$ ratio from simple and barren pegmatites of the second type to the elbaitic gem-rich pegmatites of the first group.

However, in the second one, the $\mathrm{Ta} /(\mathrm{Ta}+\mathrm{Nb})$ and $\mathrm{Mn} / \mathrm{Fe}$ ratios in columbite-tantalite increase, simultaneously, while moving away from anatectic root (Fig. 3).

Tourmalines Black tourmalines of the second pegmatite group have been found in Caparaó-Espera Feliz pegmatite district and they are strikingly absent in the pegmatites of Santa Maria do Itabira district. The schorl composition is common in these tourmalines.

All analyzed tourmalines of the first pegmatite group belong to the schorl-elbaite series. The infrared spectra of these samples in the principal hydroxyl-stretching region are strikingly different (Fig. 4). These can be assigned to compositional substitution of the $\mathrm{Y}$-site indicating $2 \mathrm{R}^{2+}=\left[\mathrm{Al}(\mathrm{Y})+\mathrm{Li}^{+}\right]$as the principal substitution mechanism. In the São José da Safira region, the values of $\mathrm{Fe} / \mathrm{Mn}$ ratio of tourmalines

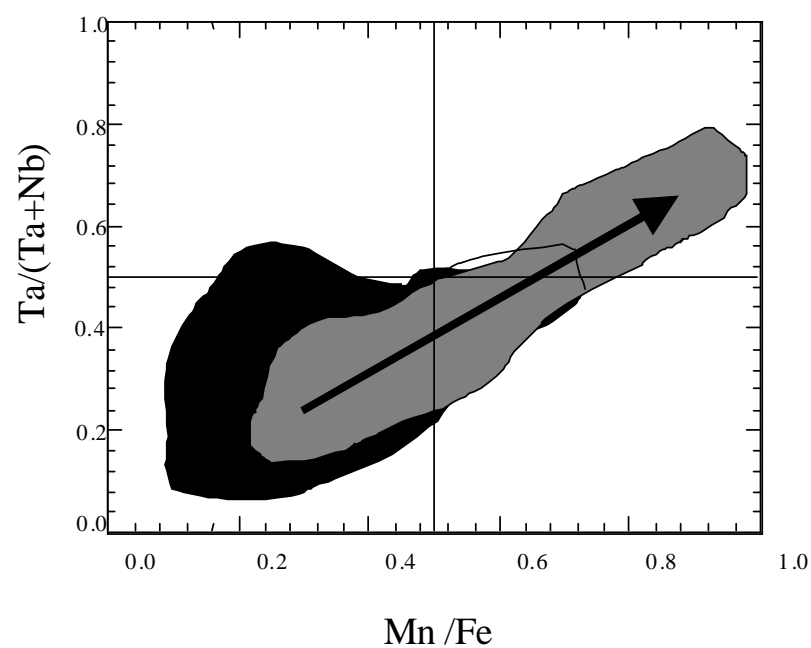

Figure 3-Compositions of the columbite-tantalite bearing the first pegmatites group (hashed area) and the second pegmatites group (black area) in the columbite-tantalite-tapiolite quadrilateral.

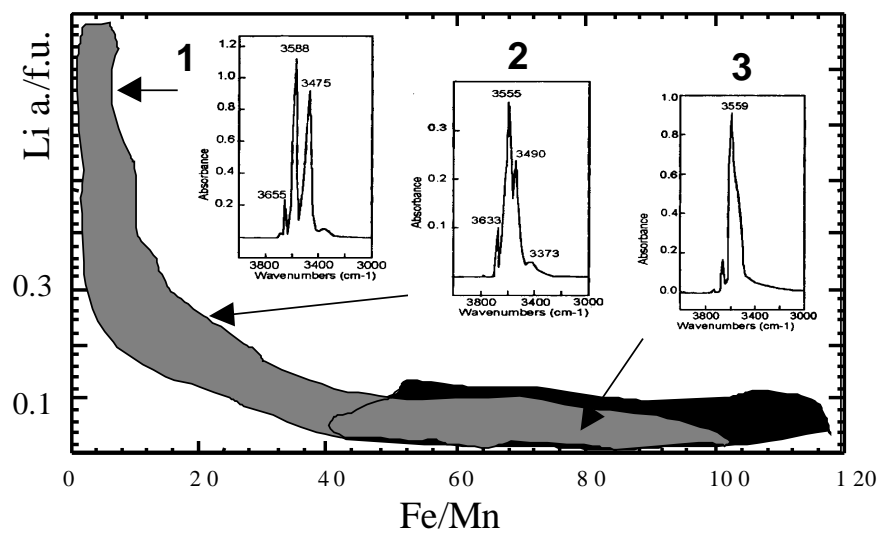

Figure 4-The infrared spectra of these tourmaline samples, in the principal hydroxyl-stretching region, show clearly defined absorption peaks at 3475 $3490 \mathrm{~cm}^{-1}$ and $3373 \mathrm{~cm}^{-1}$. The black stain represents the less evolved bodies of Li-poor first group of pegmatites. (1-Cruzeiro; 2-Benedito; 3-Cavalo Morto).

decrease northward continuously from the simple schorl-bearing pegmatites (Cavalo Morto) to the elbaite-bearing ones (Cruzeiro). The $\mathrm{Fe} / \mathrm{Mn}$ ratio values correlate negatively with the $\mathrm{Na}$ and $\mathrm{Li}$ content (Fig. 4).

It seems evident that when the amount of $\mathrm{Li}$, proxing for $\mathrm{Al}$ and $\mathrm{Fe}$, usually occupying the Y-cation site, increase, the $3475-3490 \mathrm{~cm}^{-1}$ peaks become sharper (Fig. 4). Thus the possible associations, in the Y-cation site, in these tourmalines of the first pegmatites group are $\mathrm{Fe}^{2+}-\mathrm{Al}-\mathrm{OH}$, (in less evolved pegmatites), $\mathrm{Al}-\mathrm{Al}-\mathrm{OH}, \mathrm{Fe}^{2+}-\mathrm{Al}-\mathrm{Li}$ and Al-Al-Li (in the most evolved ones). The band $3633 \mathrm{~cm}^{-1}$ can be assigned to the $\mathrm{Fe}^{2+}-\mathrm{Al}-\mathrm{OH}$ configuration and the $3555 \mathrm{~cm}^{-1}$ one is also assigned to the $\mathrm{Al}-\mathrm{Al}-\mathrm{OH}$. The $3480 \mathrm{~cm}^{-1}$ and $3373 \mathrm{~cm}^{-1}$ bands must correspond to the associations $\mathrm{Fe}^{2+}-\mathrm{Al}-\mathrm{Li}$ and Al-Al-Li. The same result was reported by Jolliff et al. (1986) for Bob Ingersoll tourmalines. This mechanism seems to be dependent on the $\mathrm{Li}$ a./f.u. content of the tourmaline. So we can make use of the infrared spectra to characterize the different tourmaline types of the schorl-elbaite series.

The Fe, Mn, Co and $\mathrm{Zn}$ contents begin to increase with $\mathrm{Fe} / \mathrm{Mn}$ ratio, but this growth is disturbed apparently by the onset of the garnet and columbite-tantalite crystallization (Bilal et al. 1998c).

Fig. 5 shows the variation of $\mathrm{Zn}$ content in pegmatite micas, tourmalines, and columbite-tantalites with the increase of Mn content in these last minerals. Clear decrease of $\mathrm{Zn}$ content in the above minerals can be seen. It starts with the onset of well-defined Mn content values in these minerals. The same trends have been observed

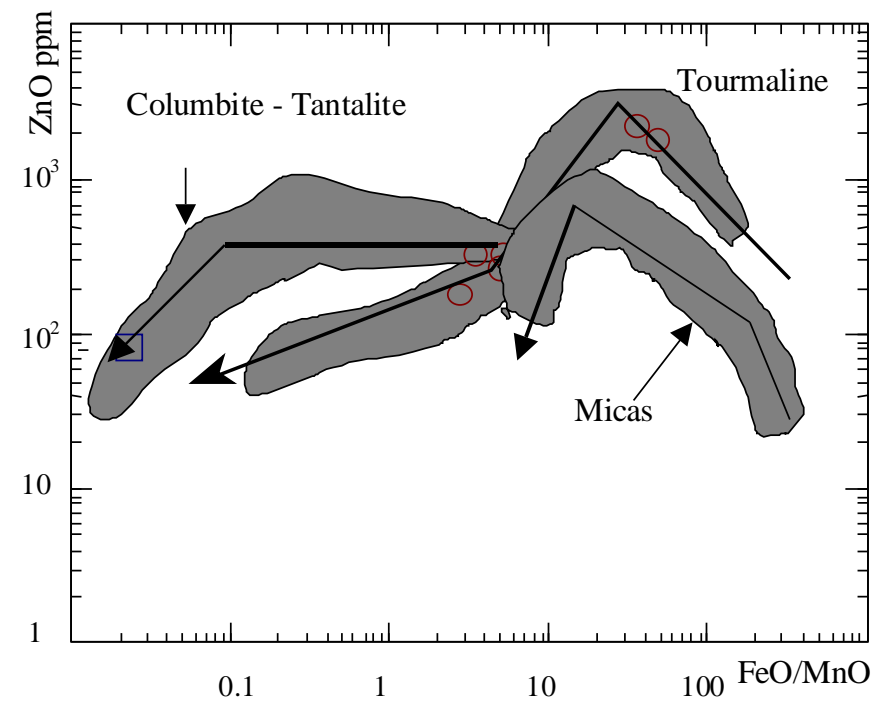

Figure 5-Fractionation trends of columbite-tantalite, micas and tourmalines in the first pegmatite group. 
in Bob Ingersoll tourmaline by Jolliff et al. (1986). However, these authors have proposed another interpretation to the minor and trace elements contents of the pegmatite accessory minerals.

CONCLUSION The geochemical features of the rare-metal pegmatites in the first pegmatite group show a more evolved fractionation trend as suggested by its greater mineral differentiation. The tourmaline and columbite-tantalite composition variations, observed in the first pegmatite group, reflect the compositional variations during the regional evolution of the pegmatites. Different systematic chemical trends seem to suggest a petrogenetic linkage among the pegmatites from São José da Safira region. So, values of Fe/ Mn ratio, obtained in tourmalines from the first pegmatite group, show the same trend as those measured in columbite-tantalite and garnets All of them decrease northward continuously from the simple pegmatites (Cavalo Morto), outcropping in lower levels, as compared to the elbaitic gem-rich ones, outcropping in Serra do Cruzeiro and emplaced in quartzites, several hundred meters above.
Values of $\mathrm{Fe} / \mathrm{Mn}$ ratio have been used as a qualitative index of fractionation, reflecting not only the regional evolution degree of pegmatites, but also the internal evolution of these bodies as well. Values of $\mathrm{Fe} / \mathrm{Mn}$ ratio correlate negatively with the Li contents.

Besides these aforementioned mineralogical and geochemical dissimilarities, the two pegmatite magmas have been generated in different ages and geological settings.

Acknowledgements This paper is the result of team-work research program concerning granitoids from Minas Gerais (Brazil) and supported since 1992 by the following Brazilian and French Institutions: CNPq, CAPES, FAPEMIG, CNEN/CDTN, Federal University of Minas Gerais (UFMG), Ecole des Mines de SaintEtienne, Jean Monnet University-Saint-Etienne, CNRS, and COFECUB. The manuscript has been improved greatly from the critical comments of an anonymous reviewer. We are also grateful to Dr. Francisco Javier Rios for his assistance during computer drafting of figures. We are indebted to all of these supporters.

\section{References}

Bilal E, César-Mendes J., Correia-Neves J.M. 1994. Os nióbio-tantalatos dos pegmatitos da região de São José da Safira, Estado de Minas Gerais.- In: SBG, Congresso Brasileiro de Geologia, 38, Balneário Camboriú, Boletim de Resumos Expandidos, 1:198199.

Bilal E., César-Mendes J., Correia-Neves J.M., Nasraoui M. 1997. Chemistry of some pegmatites of São José da Safira area, Minas Gerais, Brazil. Romanian Journal of Mineralogy. 78(1):4-6.

Bilal E., Nalini H.A., Horn H.A., Correia-Neves J.M., Giret A., Fuzikawa K., Fernandes M.L., Mello F., Moutte J. 1998a. Neoproterozoic granitoid suites of Rio Doce Region, Brazil. In International Conference on Precambrian and Craton Tectonics, Ouro Preto, Brazil. Abstracts Volume: 41-43.

Bilal E., Marciano V.R.P.R.O., Correia Neves J.M., Fuzikawa K., Riffel B.F., Nalini H Fernandes M.L., Nasraoui M. 1998b. Altération hydrothermale des monazites-(Ce) des pegmatites du district de Santa Maria de Itabira (Minas Gerais, Brésil). Compte Rendus de l'Academie des Sciences. 326, série IIa:1-8.

Bilal E., César-Mendes J., Correia-Neves J.M., Nasraoui M., Fuzikawa K. 1998c Chemistry of tourmalines in some pegmatites of São José da Safira area, Minas Gerais, Brazil. Journal of the Czech Geological Society, 43(1-2):33-38.

Correia-Neves J.M. 1997. Província Pegmatítica Oriental do Brasil. In: DNPM/CPRM (ed.) Principais Depósitos Minerais do Brasil. Vol. IV, Parte B, Brasília, 343-371.
Correia-Neves J.M., Pedrosa Soares A.C., Marciano V.R.P.R.O. 1986. A Província Pegmatítica Oriental do Brasil à luz dos conhecimentos atuais. Rev. Bras. Geociências. 16(1):106-118.

Correia-Neves J.M., Pedrosa Soares A.C., Marciano V.R.P.R.O., Monteiro R.L.B.P., Fernandes M.L.S. 1987. Granitoids and Pegmatites from the northern section of the eastern Brazilian pegmatite Province. In: International Symposium on Granites and Associated Mineralizations (ISGAM/87), Salvador. Excursion Guides Book: 123144.

Fuzikawa K., César-Mendes J., Correia-Neves J.M., Pimenta M.A., Bilal E. 1996. Evolução do fluido aquo-carbônico nos estágios tardios de cristalizaçào no pegmatito do Cruzeiro, São José da Safira, MG: As evidências mostradas pelo estudo de inclusões Cruzeiro, São José da Safira, MG: As evidências mostradas pelo estudo de inclusões
fluidas - In: SBG, Congresso Brasileiro de Geologia, 39, Salvador, Anais 7: 474476.

Jolliff B.L., Papike J.J., Shearer Ch.K. 1986. Tourmaline as a recorder of pegmatite evolution: Bob Ingersoll pegmatite, Black Hills, South Dakota - American Mineralogist, 71:472-500.

Contribution IGC-087

Received February 25, 2000 Accepted for publication May 26, 2000 